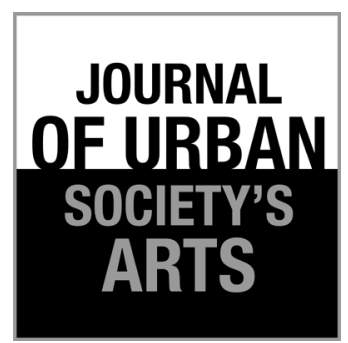

Volume 4 Nomor 2,

Oktober 2017: 103-109

\section{Fungsi dan Upaya Pelestarian Tradisi Sorong Serab Aji Krama di Desa Penujak Kabupaten Lombok Tengah}

\author{
Baiq Widya Rahmasari dan Robby Hidajat
}

Program Studi Pendidikan Seni Tari dan Musik, Jurusan Seni dan Desain

Fakultas Sastra, Universitas Negeri Malang

Tlp. -, E-mail: baiqwidya07@gmail.com

\begin{abstract}
ABSTRAK
Tradisi Sorong Serah Aji Krama adalah peristiwa adat pada penyelenggarakan pernikahan dikalangan masyarakat bangsawan Sasak di Lombok Tengah, akan tetapi tradisi itu telah menjadi pedoman umum pernikahan pada masyarakat suku Sasak. Dewasa ini tradisi Sorong Serah Aji Krama mengalami kemunduran karena perkembangan gaya hidup, sehingga masyarakat tidak mampu mendapatkan referensi yang cukup untuk melaksanakannya. Memperhatikan melemahnya pemahaman masyarakat Sasak terhadap tradisi Sorong Serah Aji Krama itu digunakan sebagai pokok permasalahan, yaitu (1) bagaimana fungsi tradisi Sorong Serah Aji Krama, (2) apa upaya yang dilakukan oleh masyarakat suku Sasak untuk mempertahankan tradisi Sorong Serah Aji Krama. Penelitian ini menggunakan kualitatif dengan metode fungsional. Narasumber kunci penelitian ini pemangku adat dan pemuka masyarakat kalangan bangsawan Sasak. Hasil penelitian ini (A) Fungsi tradisi Sorong Serah Aji Krama meliputi (1) Religi dan (2) sosial, dan (B) upaya pelesatrian Sorong Serah Aji Krama meliputi (1) membangun organisasi pelaksana tradisi Sorong Serah Aji Krama, (2) pembinaan dan pelatihan pelaksanaan tradisi Sorong Serah Aji Krama pada generasi muda, (3) memasukan tradisi Sorong Serah Aji krama sebagai muatan lokal pelajaran sekolah, dan (4) ditampilkan sebagai atraksi pariwisata.
\end{abstract}

Kata kunci: pernikahan; tradisi; sasak; atraksi pariwisata

\begin{abstract}
Functions and Efforts to Preserve Tradition Sorong Serah Aji Krama in Penujak Village, Central Lombok Regency. The Sorong Serah Aji Krama Tradition is a customary event at a wedding ceremony among the Sasak noble people in Central Lombok, but that tradition has become the general guidance of marriage to the Sasak people. Today the tradition of Sorong Serah Aji Krama is declining due to the development of lifestyle, so that the people are unable to get enough references to implement it. Taking into account the weakening of Sasak people's understanding of the Aji Krama Serge A tradition is used as the subject matter, namely (1) how is the function of the Sorong Serah Aji Krama tradition, (2) what efforts are made by the Sasak people to maintain the Sorong Serah Aji Krama tradition. This research uses qualitative with functional method. The key informant of this research is the adat stakeholder and community leader of Sasak nobility. The results of this study (A) The function of the tradition of Sorong Serah Aji Krama include (1) Religion and (2) social, and (B) Sorong Serah Aji Krama pelesatrian efforts include (1) build the implementing organization Sorong Serah Aji Krama tradition, (2) and training in the implementation of the Aji Krama Sorong Serah tradition in the younger generation, (3) incorporating the tradition of Sorong Serah Aji krama as the local content of school lessons, and (4) presented as a tourism attraction.
\end{abstract}

Keywords: wedding; tradition; sasak; tourism attraction 


\section{Pendahuluan}

Tradisi pernikahan adat suku Sasak di lombok yang disebut sorong serah aji krama pada saat ini mengalami kemunduran. Penyebabnya adalah perkembangan gaya hidup, arus globalisasi, media komunikasi sosial, budaya luar yang begitu mudah masuk di kalangan generasi muda di Lombok. Secara internal disebabkan oleh kurangnya komunikasi antara masyarakat bangsawan suku Sasak dengan pemangku adat.

Pengaruh internal dan eksternal di kalangan masarakat susu Sasak mengakibatkan fungsi tradisi sorong serah aji krama mengalami kerancuan, bahkan pelaksanaannya tidak lagi memiliki pedoman yang jelas.

Tradisi sorong serah aji krama pada pernikahan adat di lingkungan masyarakat suku Sasak ini pada awalnya digunakan hanya untuk kalangan masyarakat bangsawan Sasak. Karena perluasan fungsi, tradisi yang dimiliki kaum bangsawan ini juga digunakan oleh masyarakat suku Sasak secara umum. Pada awalnya tata cara pernikahan di lingkungan suku Sasak menggunakan pedoman syariat Islam, yaitu ijab qabul. Masyarakat suku Sasak merasa pernikahan secara syariat Islam masih belum lengkap jika tidak menggunakan tata cara pernikahan secara adat. Tradisi sorong serah aji krama ini kemudian menjadi syarat sahnya pernikahan menurut adat suku Sasak. Sebagaimana yang diungkapkan oleh Lalu Bayu Windia (2006:162) dalam bukunya berjudul Manusia Sasak Bagaimana Menggaulinya? Prosesi terpenting dari seluruh rangkaian adat pernikahan suku Sasak adalah Sorong serah aji krama. Peristiwa ini pada dasarnya adalah 'sidang mejelis adat.' Tujuannya untuk penyelesaian persoalan status sosial pihak keluarga laki-laki dan perempuan serta implikasi seluruh persoalan adat bagi seorang laki-laki sebelum dan sesudah menikah, termasuk tradisi yang mewajibkan seorang laki-laki mengambil atau membawa lari anak gadis untuk dinikahi.

Sorong Serah Aji Krama sebagai sebuah tata cara pernikahan adat memiliki impilikasi sosial. Lalu Bayu Windia (2006:162) menjelaskan bahwa "Tradisi sorong serah aji krama ini merupakan pengabsahan atau peresmian dalam pernikahan agar para pengantin memperoleh hak-haknya secara adat. Sebaliknya, jika prosesi sorong serah aji krama atau sidang majelis adat ini tidak dilaksanakan maka kedua pengantin akan kehilangan hak-hak adat misalnya hak atau status sosial atau gelar-gelar adat bagi anak yang akan dilahirkan kelak. Selain itu, ada kemungkinan bahwa kedua pengantin akan kehilangan hak dalam soal warisan harta benda". tradisi pernikahan itu adalah suatu tata cara untuk mendapatkan pengakuan status, kewenangan, dan hak-hak seseorang secara adat. Sebaliknya jika prosesi tradisi Sorong Serah Aji Krama ini tidak dilaksanakan maka kedua pengantin akan kehilangan hak-haknya di dalam adat, misalnya status sosial serta gelar kebangsawanan dihilangkan. Bagi anak dan keturunannya akan kehilangan hak waris dari orang tuanya. Memperhatikan pentingnnya tradisi Sorong Serah Aji Krama yang pada saat ini mengalami pelemahan, maka penelitian ini ditujukan untuk mengkaji fungsi tradisi Sorong Serah Aji Krama dan upaya untuk pelestariannya.

\section{Metode Penelitian}

Penelitian ini menggunakan pendekatan kualitatif dengan metode fungsional. Data yang dikumpulkan difokuskan pada keteragan, pernyataan, dan pendapat dari narasumber dengan metode pengambilan data berupa wawancara. Narasumber kunci pada penelitian ini adalah Lalu Dikjaya (45 tahun) sebagai pemangku adat sekaligus kepala desa Penujak, Lalu Herman (43 tahun) sebagai salah satu pemuka masyarakat kalangan bangsawan Sasak. H. Lalu Ahmad Rupawan (65 tahun) sebagai sesepuh adat di desa Penujak, Lalu Fuadi (55 tahun) sebagai salah satu kepala dusun di desa Penujak.

Teknik pengumpulan data menggunakan wawancara, observasi, dan dokumentasi. Lokasi penelitian ini adalah desa Penujak, kecamatan Praya Barat, kabupaten Lombok Tengah karena sebagian besar penduduknya didominasi oleh masyarakat kalangan bangsawan.

Peneliti mengecek hasil temuan untuk mendapatkan keabsahan data penelitian menggunakan teknik triangulasi sumber dan 
metode. Teknik triangulasi sumber ini digunakan dengan cara membandingkan dan mengecek kembali kekuatan dan kepercayaan untuk informasi yang telah diperoleh melalui wawancara, observasi serta dokumentasi. Peneliti menggunakan perbandingan antara informan atau narasumber utama dengan informan pendukung.

\section{Paparan Data dan Analisis}

Pelaksanaan pernikahan itu memperlihatkan masyarakat suku Sasak memiliki peraturan dalam melaksanakan tradisi. Pelaksanaan tradisi atau hukum adat menggunakan sistem adat. Sistem adat tertinggi dipegang oleh Pengemong adat atau kepala desa yang berkuasa menjalankan sistem adat. Sistem adat inilah yang nantinya akan berperan dan mengurus segala pernikahan yang akan dilaksanakan. Mulai dari proses selabar, sejati, nuntut wali, akad nikah, sorong serah aji krama, nyongkolan, balas ones nae. Di antara sejumlah tata cara adat itu, sorong serah aji krama yang menjadi bagian yang penting.

\section{Pelaksanaan Sorong Serah Aji Krama}

Peneliti menyaksikan peristiwa pernikahan yang lengkap di rumah Lalu Pardi pada hari Minggu tanggal 5 Februari tahun 2017 di Dusun Montor, Desa Penujak, Kecamatan Praya Barat, Kabupaten Lombok Tengah. Proses pelaksanaan tradisi pernikahan adat menurut tradisi suku Sasak cukup panjang, yaitu sebagai berikut (1) Melamar dilakukan oleh kedua belah pihak keluarga jika kedua belah pihak dari laki laki dan perempuan telah ada kesepakan awal. (2) Meruput ini bukan kawin paksa melainkan hasil musyawarah antara dua keluarga yang masih memiliki hubungan kekerabatan yang erat dan bertujuan untuk memperkuat tali silaturrahim antar sesama keluarga dan agar si gadis tidak menikah dengan orang diluar kalangannya. (3) Mbait atau Merangkat. Prosesi Mbait inilah yang sering salah diartikan bahkan diterjemahkan secara dangkal sebagai kawin lari dengan image buruk yang melekat dialamnya. Mbait secara harfiah berarti mengambil. Dilakukan dengan sebuah skenario yaitu si gadis diambil "diam-diam" tanpa sepengetahuan orangtuanya. Sebenarnya selama proses si gadis menerima beberapa laki laki yang datang menjajaki (midang) orangtua sudah mampu untuk menangkap tanda kepada laki laki anak gadisnya akan menjatuhkan pilihan, tetapi yang tidak diketahui pasti adalah hari-H laki laki pilihan anaknya akan melaksanakan Mbait (mengambil) anak gadisnya. Bisa terjadi seorang gadis dicintai oleh lebih dari satu orang laki-laki. Jika kebetulan salah satu diantaranya terbilang masih keluarga dekat si gadis, maka orangtua si gadis akan mengalami suasana dilematis. Orangtua mengambil jalan, seakan-akan bahwa keputusan diserahkan sepenuhnya kepada anak gadisnya. Menegaskan keputusan menikah benar benar tanpa sepengetahuan orangtua maka skenario yang dipilih dengan cara lari kawin dengan maksud agar orangtua terhindar dari rasa bersalah atas perasaan sedih yang mungkin menimpa orangtua pemuda yang tidak terpilih. Merariq yang dilakukan dengan cara lari kawin sebenarnya telah diperhitungkan oleh orangtua akan terjadi, juga telah bisa ditebak dengan laki laki mana pilihan anak gadisnya. Peristiwa Mbait sangat penting, karena awal dari rangkaian prosesi adat yang mengandung konsekuensi luas dan rumit, baik pada waktu peristiwanya berlangsung maupun sesudahnya. Kronologi proses Mbait adalah si gadis dijemput pada malam hari di tempat yang telah disepakati kedua calon pengantin. Waktunya, sesudah tenggelam matahari, biasanya antara magrib dan isya'. Jika dilakukan disiang hari dianggap pengecut sehingga dibelakang hari pada prosesi sorong serah aji krama akan didenda, berupa tidak boleh masuk pekarangan apalagi sampai naik ke serambi. Dendanya juga sangat besar, dahulu bernilai 49.000 kepeng. Jika hal ini terjadi maka pihak laki laki akan sangat malu karena namanya tercoreng di mata masyarakat. Si gadis yang dijemput, tidak langsung dilarikan kerumah orangtua laki-laki, tetapi kerumah kerabat orangtua laki laki. Hal ini bertujuan agar keputusan menikah benar-benar keputusan kedua calon mempelai. Skenario Mbait ini dilakukan tanpa sepengetahuan keluarga calon pengantin wanita, dengan demikian untuk menghindari kecemasan orangtua calon pengantin wanita yang kehilangan anak gadisnya 
maka segera mungkin dilakukan pemberitahuan. Biasanya waktunya paling lambat tiga hari.

Pelaksanaan tradisi pernikahan sebagai berikut. (a) Sejati atau Masejati. Pemberitahuan dari pihak keluarga calon laki laki kepada keluarga calon pengantin wanita bahwa anak gadisnya benar benar telah lari kawin dengan dengan laki laki dari keluarga yang datang untuk masejati. Prosesi menikah yang diawali dengan Mbait disadari sebagai awal eristiwa yang akan membawa konsekuensi dan tanggungjawab yang berat dan rumit sesudahnya. Diberinya sayur bening daun kelor tanpa garam, sebgai pelambang perjuangan tanpa pamrih. Utusan yang ditugasi masejati, berpakaian adat, berjumlah sekurang kurangnya dua orang. Semakin tinggi status sosialnya maka utusan masejati akan lebih banyak utusannya. Mereka dilengkapi dengan dengan bawaan yang disebut sesirah. (b) Sejati merupakan pemberitahuan atau permakluman kepada pemerintah desa dengan maksud untuk dapat menjembatani kedua belah pihak serta menjaga situasi dan kondisi agar senantiasa aman. (c) Selabar merupakan penyampaian yang dilakukan oleh pihak laki laki kepada keluarga atau ahli waris dari mempelai wanita bahwa si gadis telah berjodoh atau telah diambil oleh seorang pemuda. Pemberitahuan kepada ahli waris bahwa hilangnya si gadis meninggalkan rumahnya bukan pergi jalan-jalan atau diculik dan sebagainya melainkan telah memilih seorang pemuda untuk berjodoh atau menikah dengannya. (d) Menuntut Wali bahwa pihak laki laki meminta wali untuk pelaksanaan akad nikah kepada wali dari si gadis. (e) Perbak Pucuk kegiatan membicarakan teknis tentang waktu pelaksanaan acara, biaya yang dibutuhkan untuk pelaksanaan pernikahan, serta semua yang berhbungan dengan pernikahan hingga selesai acara pernikahan secara adat, (f) sebagai proses sakral dilakukan Walimah atau Akad Nikah, tujuannya untuk menyatukan kedua mempelai dalam ikatan pernikahan.

Proses Sorong Serah Aji Krama Arti dari sorong serah aji krama ini yaitu keluarga perempuan mendorong anaknya kepada keluarga laki-laki sehingga tanggung jawab dilihat melalui sorong serah aji krama. Kedua belah pihak keluarga laki laki dan perempuan sama sama telah menyerahkan tanggungjawab tersebut kepada kedua pengantin.
Arti sorong serah aji krama adalah lambang suci dari proses awal hingga akhir pernikahan atau peresmian serta memutuskan strata sosial bagi kedua pengantin. Apa yang menjadi beban kedua orangtua secara adat belum dinyatakan sah, walaupun agama sudah sah jika sorong serah aji karma belum dilaksanakan. Maka dinyatakan sah menurut adat jika proses sorong serah aji krama telah dilaksanakan. Hal inilah yang menyebabkan adat sasak itu bersendikan syara' dan agama dari kitabullah atau Al Qur'an. (g) Nyongkolan merupakan pawai atau arak arakan pengantin yang diikuti oleh muda mudi dengan ikut dalam satu barisan yang besar. Biasanya nyongkolan diiring dengan musik tradisional Sasak yaitu gendang beleq. (h) Balas Ones Nae adalah Kunjungan yang dilakukan oleh seluruh keluarga besar dari pihak pengantin laki laki ke rumah pengantin wanita setelah nyongkolan atau arak arakan selesai dilakukan yang bertujuan agar kedua keluarga semakin saling mengenal satu sama lain.

Mengingat bagian ini merupakan tata cara yang dapat memberikan pengakuan dan penentuan posisi seseorang dan keturunanya secara adat. Pada penelitian ini didapatkan dua aspek pada sorong serah aji krama, pertama fungsi religi dan kedua fungsi sosial.

\section{a. Fungsi Religi}

Secara bahasa, kata religi adalah kata kerja yang berasal dari kata benda religion. Religi itu sendiri berasal dari kata re dan ligare artinya menghubungkan kembali yang telah putus, yaitu menghubungkan kembali tali hubungan antara Tuhan dan manusia yang telah terputus oleh dosadosanya (Mubarok, 2003:45). Fungsi religi pada tradisi sorong serah aji krama dalam pernikahan suku Sasak memang untuk memberikan pengakuan bagi manusia, yaitu menempatkan manusia yang diciptakan Allah sebagai khalifah (pemimpin), kemudian masyarakat suku Sasak harus berpegang teguh pada akidah atau ajaran Islam maka dibebankan satu hukum adat melalui sorong serah aji krama. Anak yang akan lahir nantinya dari pasangan pengantin harus benar-benar berpegang teguh serta menjalankan aturan Allah yang ada di Al Quran dan hadist. 
Sorong serah aji krama bertujuan membebankan hukum adat pada suami istri yang berkewajiban menjaga keturunannya agar akidah dan keyakinannya. Sorong serah aji krama game suci lambang adat. Pemahaman yang diyakini oleh masyarakat suku Sasak sebagai berikut (1) Aji berarti datu (raja) dalam agama Islam disebut khalifah. (2) Krama berarti hukum atau undangundang (peraturan). (3) Game suci artinya agama Islam, dan (4) Lambang adat artinya ketentuan etika moral sosial yang tumbuh dan disepakati bersama oleh masyarakat suku Sasak (wawancara dengan Dikjaya, selasa, 23 Januari 2017).

Kedudukan atau strata sosial masyarakat suku Sasak berdasarkan penerapan akidah Islamiah ditetapkan ketentuan-ketentunanya dalam pelaksanaan sorong serah aji krama, yaitu (1) Utama. Aji krama dihitung seratus (100) yang dibagi menjadi nampak lemah 40. Olen sebanyak 60. Sirah aji berupa bokor kuning yang berisi kain putih,hitam, keris atau dinamakan kebo turu. Salin dede yang berisi ceraken, stagen (sabuk), periuk, tepak (paso), kain warna warni, kemeq, semprong, atau bilah bambu dengan rangkap (ani ani). Beban dari tingkat utama ini sangatlah berat. Maksud aji krama dihitung seratus (100) bermakna bahwa 100 itu Allah dan 99 nama lain dari Allah. Kalangan bangsawan dari utama ini harus mampu mengenal secara keseluruhan rahasia rahasia yang terkandung di alam semesta ini. Dia pun harus mampu mengenal Asmaul Husna atau 99 nama nama Allah serta Márifat Allah. Mengenal Asmaul Husna bukan hanya sekedar mengenal dan mengetahui melainkan harus meyakininya serta berpegang teguh pada ajaranNya. (2) Madya. Aji krama dihitung enam puluh enam (66) yang dibagi menjadi nampak lemah 20. Olen sebanyak 46. Sirah aji berupa bokor kuning yang berisi kain putih, hitam, keris atau dinamakan kebo turu. Salin dede yang berisi ceraken, stagen (sabuk), periuk, tepak (paso), kain warna warni, kemeq, semprong, atau bilah bambu dengan rangkap (ani ani). Beban tingkat madya atau pertengahan ini cukup berat. Maksud dari aji krama yang dihitung enam puluh enam (66) adalah Allah itu $A l$ Wahid Yang Maha Tunggal. Orang dari tingkatan madya ini harus paham bahwa Tuhan itu satu atau tunggal dan tidak ada Tuhan selain Dia. Aktifitas atau kegiatan apapun yang dilakukan diniatkan semata mata hanya karena Allah dan tidak ada niat yang lain. Orang dari tingkatan madya ini pun harus mampu memahami hakikatnya bahwa dia diciptakan sebagai manusia di dunia oleh Allah Yang Maha Tunggal, dan (3) Niste. Aji krama dihitung tiga puluh tiga (33). Nampak lemah sepuluh (10). Olen sebanyak dua puluh tiga (23). Sirah aji berupa bokor kuning yang berisi kain putih, hitam, keris atau dinamakan kebo turu. Salin dede yang berisi ceraken, stagen (sabuk), periuk, tepak (paso), kain warna warni, kemeq, semprong, atau bilah bambu dengan rangkap (ani ani). Aji krama yang dihitung tiga puluh tiga (33) tingkat biasa ini lebih mudah. Aji krama dihitung 33. artinya setara dengan jumlah bilangan zikir atau mengingat Allah (wawancara dengan Lalu Sirajuddin, Selasa, 7 Februari 2017).

Selanjutnya, Lalu Dikjaya menjelaskan kedudukan manusia di dunia, manusia diciptakan untuk beribadah kepada Allah dan senantiasa terus berzikir. Manusia juga harus mampu melaksanakan kewajiban yang dibebankan atas dirinya dan juga mewajibkan dirinya untuk melaksanakan hal hal baik dengan tanggungjawab yang telah dibebankan kepadanya (wawancara dengan Dikjaya, Selasa, 23 Januari 2017).

\section{b. Fungsi Sosial}

Teori ini dikembangkan oleh Bronislaw Malinowski (1884-1942) yang mengajukan teori fungsionalisme yang berasumsi bahwa semua unsur kebudayaan merupakan bagianbagian yang berguna bagi masyarakat di mana unsur unsur tersebut terdapat. Dengan kata lain, pandangan fungsional atas kebudayaan menekankan bahwa setiap pola tingkah-laku, setiap kepercayaan dan sikap yang merupakan bagian dari kebudayaan suatu masyarakat, memerankan fungsi dasar didalam kebudayaan yang bersangkutan. Seperti halnya pada suku lain, Suku Sasak juga mengenal stratafikasi atau pelapisan sosial. Pada dasarnya tidak ada perbedaan yang mencolok antara golongan bangsawandan rakyat kalangan suku Sasak, kecuali pada panggilan, gelar dan hak hak istimewa yang melekat pada dirinya. Pelapisan sosial di kalangan suku Sasak pada intinya terbagi menjadi 3 golongan 
yaitu golongan Utama, madya, dan Nista. Beberapa aspek yang menjadikan bangsawan golongan utama dan madya menjadikan dirinya dikalangan sosial masyarakat sebagai pengambilan keputusan penting, memikul tanggungjawab masyarakat secara keseluruhan, serta sikap, adab yang begitu sopan dan santun. Watak rendah hati bangsawan utama dan madya menjadi contoh yang baik dalam kalangan masyarakat.

Masyarakat juga memiliki sebuah sistem adat dalam upaya penyelesaian pernikahan. Terutama yang terjadi ketika keputusan seorang gadis untuk menikah dengan laki laki yang menjadi pilihannya dengan cara lari kawin yang menjadikan keluarga dari pihak laki laki dan perempuan belum bisa berdamai. Agar tidak terjadi perselisihan antara keluarga pihak laki laki dan perempuan karena proses Mbait atau lari kawin yang dilakukan oleh kedua calon pengantin. Selain itu, agar tidak terjadi pertengkaran antara laki aki yang tidak dipilih oleh si gadis, sehingga proses sorong serah aji krama ini dilakukan sebagai bentuk penyelesaian pernikahan.

Pernikahan yang berlangsung antara golongan tinggi atau utama, madya dengan golongan yang ada dibawahnya menjadikan munculnya penurunan golongan atau gelar kebangsawanan. Misalnya jika seorang laki laki dari golongan utama yang disebut Raden menikah dengan perempuan dari golongan utama atau disebut Dinde maka dari pernikahannya akan melahirkan keturunan yang berhak atas kedudukan orangtuanya. Mendapat gelar kebangsawannya dan strata sosialnya tetap dalam golongan utama. Sebaliknya, jika seorang laki laki dari golongan utama menikah dengan perempuan dari luar golongan utama maka strata sosialnya pun akan turun menjadi golongan madya atau menengah. Jika laki laki dari kalangan niste menikahi perempuan dari golongan utama atau madya maka nilai strata sosial perempuan ini akan hilang bahkan akan dikeluarkan dari kebangsawanannya. Akibatnya, perempuan tersebut tidak boleh untuk pulang kembali dan keturunannya tidak berhak mendapatkan gelar kebangsawan orangtuanya.

Fungsi Sosial golongan utama adalah sebagai pengambilan keputusan tertinggi, menjadi panutan serta pembuat, penggagas dan penentu sistem adat.
Golongan madya bertugas untuk melindungi wilayah serta menjalankan dan memastikan sistem adat yang telah ditentukan oleh golongan utama untuk dijalankan di kalangan masyarakat.

\section{c. Upaya Pelestarian Tradisi Sorong Serah Aji Krama}

Upaya pelestarian tradisi Sorong Serah Aji Krama di desa Penujak, kabupaten Lombok Tengah. Di tingkat Pemerintah daerah (PEMDA) Lombok Tengah, membentuk pelatihan-pelatihan, serta menerbitkan buku panduan pelaksanaan tradisi sorong serah aji krama, perangkat pelestarian yang lain adalah (1) membangun organisasi pelaksanaan tradisi sorong serah aji krama, dengan demikian masyarakat nanti akan ditunjuk serta bergabung dalam organisasi ini yang akan menjalankan tradisi tersebut di masyarakat. Tradisi sorong serah aji krama yang dibangun dan disepakati tokoh masyarakat bangsawan serta pemangku adat berfungsi penting, dan bersifat sakral. Hal ini yang menyadarkan Lalu Dikjaya, selaku pengemong adat (ketua adat) dan Lalu Herman, tokoh kalangan bangsawan Sasak. Menetapkan upaya yang dilakukan masyarakat bersama pemerintah daerah setempat, masyarakat bangsawan serta tokoh adat untuk melestarikan tradisi ini dengan cara masyarakat memberikan dukungan penuh serta membangun krama adat atau organisasi pemerintahan lokal. Krama desa dan krama gubuk ditetapkan sebagai pelaksana teknisnya, (2) pembinaan dan pelatihan pelaksanaan tradisi sorong serah aji krama pada generasi muda, untuk mengetahui proses serta tata cara pelaksanaan tradisi tersebut, (3) memasukan tradisi sorong serah aji krama sebagai muatan lokal pelajaran sekolah. Agar tradisi tersebut juga berimplikasi pada seluruh generasi muda, Lalu Sirajuddin, sebagai koordinatgor guru muatan lokal memasukan tradisi sebagai pelajaran budaya (wawancara dengan Lalu Sirajuddin, Selasa, 7 Februari 2017), dan (4) penyajian atraksi pariwisata. Melalui dinas pariwisata akan berupaya untuk menciptakan atraksi budaya, yaitu replika pelaksanaan tradisi sorong serah aji krama sebagai sajian wisata. Pertunjukan berbentuk atraksi budaya yang diproduksi oleh dinas pariwisata lokal maupun tingkat provinsi. Bentuk pertunjukan atraksi budaya itu tradisi 
sorong serah aji krama secara utuh, secara singkat, kurung lebih berdurasi 1 jam. Harapannya, para wisatawan dapat memahami nilai-nilai spiritual dan sosial yang berlalu dalam masyarakat adat suku Sasak di Lombok Tengah.

\section{Simpulan}

Tradisi sorong serah aji krama di Desa Penujak Kabupaten Lombok Tengah, penting dalam kehidupan sosial masyarakat suku Sasak di Lombok, mengingat aspek fungsinya adalah (1) penyelesaian pernikahan adat suku Sasak yang dianggap sebagai sahnya pernikahan secara adat, (2) membebankan hukum adat pada suami istri yang berkewajiban menjaga keturunannya agar akidah dan keyakinannya tidak berpindah pada ajaran Islam, (3) menjalain sistem kekerabatan untuk mempertahankan eksistensi hirakis bangsawan berdasarkan strata sosial Utama, Madya, dan Niste. (4) penetuan strata sosial bagi kedua pengantin, (5) menetapkan hak adat dan status sosial yang diwariskan kepada keturunannya, dan (6) masyarakat bangsawan dan pemangku adat berupaya terus melestarikan tradisi sorong serah aji krama dengan cara membangun organisasi, melaksanakan pembinaan atau pelatihan, meminta dukungan kepada pemerintah untuk menambah wawasan dengan muatan Lokal, serta menjadikannya sebagai atraksi pertunjukan pariwisata.

\section{Kepustakaan}

Kurniawan, H., 2009. Sastra Anak Dalam kajian
Strukturalisme, sosiologi hingga penulisan Kreatif. Yogyakarta : Graha Ilmu.

Mangkunegara, A.P. 2001. Manajemen Sumber Daya Manusia Perusahaan. Bandung : Remaja Rosdakarya.

Prawirosentono, S., 1999.Manajemen Sumber Daya Manausia, Kebijakan Kinerja Karyawan. Yogyakarta : BPFE.

Wirabakti, dkk., 2010. Prosesi Titi Tata Adat Sasak Dalam Aji Krama. Mataram : Pustaka Widya.

Windia, B.L., 2006.Manusia Sasak Bagaimana Cara Menggaulinya?.Yogyakarta: Genta Press

Zamroni. 1992. Penganar Pengembangan Teori Sosial. Tiara Wacana: Yogyakarta. 2007. Al-Qur'an dan Terjemahnya. Jakarta : CV Darus Sunnah.

Ipunk. 2013. Definisi Religi. http://ipunknasa. blogspot.co.id/2013/03/definisi-religi-agama. html. diakses tanggal 10 Juni 2017 pukul 23.00 .

\section{Informan}

Lalu Dikjaya (49 tahun). Kepala Desa dan Pengemong Adat Desa Penujak

H. Lali Ahmad Rupawan (69 tahun). Mantan Kepala Desa Penujak, sesepuh adat serta purnawirawan.

Lalu Fuadi (59 tahun). Kepala Dusun Dayen Peken.

Lalu Herman (53 tahun). Pemuka masyarakat kalangan bangsawan.

Lalu Sirajuddin (54 tahun). Guru muatan lokal salah satu SMP di desa Penujak. 